\title{
"Go get a job right after you take a bath": Occupy Wall Street as Matter out of Place
}

\author{
Matthew Bolton (Pace University), Stephen Froese (Princeton) and Alex Jeffrey (Cambridge)
}

\begin{abstract}
Anthropological studies of purity reveal how notions of cleanliness influence political and social life. During its 2011 Zuccotti Park occupation in Lower Manhattan, Occupy Wall Street (OWS) contested spatial and symbolic manifestations of neoliberalism by re-inserting Otherness into sanitized and privatized space. But the demonstration provoked reactions from politicians and news media that entwined discourses of cleanliness and productivity (such as Newt Gingrich's riposte to the protestors: "Go get a job right after you take a bath"). This ethnographic study argues that such representations had spatial and political effects. In particular, our account illuminates the plural agency of Occupiers, where resistance to depictions of dirt and idleness existed alongside the use of such discourses to discipline each other. We trace a discursive legacy of these events as notions of productivity and cleanliness have circulated within activist responses to 2012's Superstorm Sandy and the 2014 Flood Wall Street mobilization.
\end{abstract}

\section{Keywords}

Occupy Wall Street, Purity, Risk, Productivity, Cleanliness, Dirt

\section{Introduction}

In the midst of his campaign for the 2012 Republican Presidential nomination, Newt Gingrich was asked what he thought of the Occupy Wall Street movement. His view, he said, was "simple": "Go get a job right after you take a bath." Gingrich argued that the Occupiers "start with the premise that we all owe them everything. They take over a public park they didn't pay for," and "go to bathrooms they didn't pay for." For Gingrich, one's right to the city and its public spaces is predicated on one's ability to earn and use money. His perception of OWS as 'dirty' - "take a bath" - presents those unable or unwilling to participate in the neoliberal economy as 'unclean.' ${ }^{1}$ His response framed OWS in the discourses of purity, cleanliness, productivity and removal of pathogens that have often been used to dehumanize those who have resisted, whether in petty or systematic ways, the neoliberal enclosure of the New York City's urban environment. The two parts of his riposte "get a job" and "take a bath" sum up well the two main discursive strategies used to discredit OWS's Occupation of Zuccotti Park. They also lie within a broader right-wing discourse that casts those who object to inequality as "dependent" and wasteful 
"takers", who "believe they are victims," as Mitt Romney and his running mate Paul Ryan put it. ${ }^{2}$ These discourses shaped how authorities dealt with OWS in New York City. Attempts to clear OWS from Zuccotti Park were justified in terms of health and hygiene. OWS resisted this by itself co-opting the discourse and performance of sanitation. Its Sanitation Working Group coordinated the cleaning of the park and artists used representations of brooms (and the City's street-cleaning logo) as a symbol of the occupation, with the slogan: "sweeping away Wall Street corruption." But as OWS struggled with the more unruly inhabitants of Zuccotti Park, Occupiers began to use discourses of pollution and unproductivity to marginalize and discipline each other.

In this article we use the example of OWS in New York City to examine the role of pollution discourses in the policing and marginalization of dissent in the neoliberal global city. The article is rooted in our participant observation in OWS: one of the authors (Stephen Froese) was a member of the OWS Architecture Working Group and later mobilized with Occupy Sandy; another (Matthew Bolton) participated in the Occupation as well as the 2014 Flood Wall Street action. We build on Julian Brash's excellent (though brief) analysis of OWS and purity discourses, ${ }^{3}$ using the theoretical work of Mary Douglas, Zygmunt Bauman and others to show how neoliberal urbanism values human lives differentially, based on their contribution to the productivity of capital and ability to consume. The neoliberal city is conceived not as a messy haven for diasporas and dissenters - what Marshal Berman called "sloppy" space ${ }^{4}$ - but rather as a smooth engine of global consumerism. Those who do not fit well in the city as a playground for the global cosmopolitan elite are disciplined and marginalized through the market (rising rent and food prices) and aggressive policing. ${ }^{5}$ These measures are justified and legitimated through discourses that cast the poor, the petty criminal, the homeless and dissenter as "waste" - wasting space and resources that could be more productively leveraged and monetized. OWS sought to dramatize this by visibly placing themselves - human waste - at the very core of the global financial system. In doing so, they were subjected both to police violence but also discursive violence that coded them as unproductive, dirty and dangerous.

We make three, interconnected, arguments. The first argues that discourses of dirt and unproductivity constitute a form of urban geopolitics, where dominant understandings of hygiene and order provide legitimacy for punitive martial interventions. Second, we argue for a more plural sense of activist agency within the Occupy movement, where Occupiers themselves resisted, co-opted and sometimes deployed the language and practice of productivity and cleanliness. While the main response to accusations of uncleanliness involved the organization of a Sanitation Working Group, Occupiers also deployed discourses of pollution within their own camp to discipline each other. Finally, we argue that there has been an ongoing discursive legacy of framing protesters as unclean and indolent. After the end of the Zuccotti Park Occuption - in the Occupy Sandy and Flood Wall Street actions - they have sought to recast themselves as more productive than the city government (in responding to Superstorm Sandy) and as cleansing the global system of capitalism's polluting effects.

From these three arguments stems three contributions to theory and practice. First, we intervene in theoretical conversations about the social functions of purity and productivity discourses. Rather than develop a completely new theoretical framework, we show how Mary Douglas' study of purity and danger - though written in 1966 - remains a valuable lens through which to examine how dissent is 
discursively discredited. We aim to show that people in authority often cast those disruptive of the status quo as "dirty" and "unproductive". However, there is not a binary or one-way relationship between the powerful creators of the discourse and passive recipients of it. Indeed, activists (by the very nature of the term) are discursively active, appropriately these discourses for their own political goals by satirizing, redirecting, flipping and recirculating them. Second, as committed activists ourselves, we aim to highlight the strategic challenge posed by purity discourses which so often form part of the right-wing reaction to progressive social movements. In our participant observation in Zuccotti Park we noticed that many white, middle class Occupiers were surprised and caught off guard when confronted with the claim that they were "dirty" - they were unfamiliar with being so labelled. In highlighting these examples of purity discourses we aim to call activists' attention to the need to prepare a strategic and discursive response to the likely depiction of their mobilization as wasteful and a source of contagion. Third, we would like to "red flag" the dangers of labelling protestors as dirty. We hope that in showing how "dirt rhetoric" often precedes authoritarian measures against dissent, we can warn observers of social movements - journalists, academics, commentators - to call out such discourse when they see it.

In the next section we conduct a review of the theoretical literature on the intersections between pollution discourses and neoliberal urbanism, focused on the work of Mary Douglas. We then look at how these dynamics have played out in Lower Manhattan and how OWS's encampment contested their spatial and symbolic manifestations in the Financial District. The next section uses the two parts of Gingrich's riposte - "get a job" and "take a bath" - to examine in depth how the Occupation's opponents deployed discourses of unproductivity and dirtiness to delegitimize OWS and justify the use of coercion against it. We follow this by showing how OWS has resisted these discourses after the end of the Occupation, demonstrating its productivity after Superstorm Sandy in 2012. Ending with a description of Occupiers casting themselves as the cleansing deluge in the 2014 Flood Wall Street demonstration, we conclude with reflections on the disturbing yet productive potential of anomalous people in the city, a normative call for urban Otherness.

While for ease of understanding we trace the interaction between Occupy and cleanliness discourses chronologically, from 2011 to 2014, we should clarify that this should not be taken to indicate a cycle of thesis, anti-thesis and synthesis or a teleological ascent to climax. The structure of this article - in which OWS is subject to, becomes complicit in, appropriates and redirects purity discourses - is a heuristic, not a straightforwardly linear narrative. Rather, like Welty et al we conceive of OWS and the discourses surrounding it are like a "palimpsest", in which notions of purity, productivity, pollution and dirt circulate simultaneously and cacophonously. In doing so, they compete, clash and influence each other in myriad interactions. ${ }^{6}$

\section{a. The Politics of Purity and Danger: A Review}

In her 1966 classic work on the anthropology of Purity and Danger, Mary Douglas argued that our beliefs about what are "dirty" objects and people are not determined by their intrinsic characteristics, but rather by a sense that they are "matter out of place." Douglas wrote that in cleaning a house we are not so much "trying to avoid disease"; we are "separating, placing boundaries, making visible statements about the home that we are intending to create out of the material house." ${ }^{8}$ 
In other words, "no single item is dirty apart from a particular system of classification in which it does not fit." ${ }^{\prime \prime}$ Cultural notions of purity, neatness and order function to create and maintain boundaries between people, places and things, reducing "intellectual and social disorder." Douglas observed that people in many different cultural settings felt threatened by "Ambiguous things" and behaviors that blurred their "great classifications of the universe." We "denounce" such anomalies, she wrote, "by calling [them] dirty and dangerous" and a threat to human health. ${ }^{10}$ In doing so, we marshal natural phenomena like disease to "avenge the broken taboos" and "defend the founding principles of society." ${ }^{11}$ Crucially for our argument, Douglas points to the systemic implications of violating pollution taboos. Unlike punishment for recognizable moral wrongdoing, the consequences of such acts are seen as contagious, spreading "harm indiscriminately...to the whole community."12 This is because dirt exists in relation to the entire social order that it violates: "Dirt ... is never a unique, isolated event. Where there is dirt, there is a system." Dirt, for Douglas, "is the by-project of a systematic ordering", in which things deemed "inappropriate elements" have been rejected. ${ }^{13}$

This sense of a system of dirt and cleanliness is evident in the work of Zygmunt Bauman. His writings on neoliberal conception of globalization has illustrated that those outside systems of formal employment and financial flows - informal workers, beggars, the unemployed - are depicted as "redundant" or "waste". Indeed the term "wastrel" - used by several right-wing bloggers to describe the Occupiers evokes both the notion of waste and vagrancy. Just as Gingrich so quickly linked 'getting a job' and 'taking a bath', Bauman shows that by discursively framing people as waste, those who refuse or are unable to participate fully in the global market economy are equated with feces, parasites, dirt and pathogens - a danger to be controlled, even eliminated. ${ }^{14}$ Mark Wigley identifies this valorization of the pristine in the white walls that adorn so many of the buildings that serve as the places of work, leisure and habitation for the financial elite. ${ }^{15}$

This sense of embodied infrastructures stalks some of the more avowedly spatial elements of Douglas's work. Pre-empting more recent work on the nature and practice of international border making, ${ }^{16}$ Douglas points out that the word sacred comes from the Latin sacer - to separate or set apart. Therefore, cultural ritual and practice separates out what is "clean" and pure from that which is threatening and impure. The presence of dirt in sacred, clean space is thus a threat to the system that maintains such a separation. ${ }^{17}$ But pristine separation is impossible and so "any given culture must confront events which seem to defy its assumptions." ${ }^{18}$ As a result, cultural notions of hygiene and purity rely upon and are produced by the ongoing exercise of political power. Pollution taboos are enforced in a variety of ways. At the most passive level, the offending dirt may simply be ignored: "so that they do not disturb these established assumptions." ${ }^{19}$ In States of Denial, Stanley Cohen explores the political and social structures that militate against the conscious recognition of unpleasant realities. $^{20}$

If we do choose to perceive the anomaly, Douglas notes a variety of responses societies take to neutralize the threat of impurity. The anomaly may be "reduced" through efforts to make it conform, "physically controlled", "avoided", "condemned" or "labelled dangerous." ${ }^{21}$ Particularly stubborn sources of perceived pollution may be punished through "social sanctions, contempt, ostracism, gossip, perhaps even police action." ${ }^{22}$ The municipal equivalent is the zoning regulation, which regulates what 
people, activities and structures can occupy what spaces. ${ }^{23}$ Ben Campkin takes this political element of Douglas' analysis further by complementing it with Kristeva's theory of abjection, "conceiving of city as a place where we are continuously forced to negotiate the abject - "what disturbs identity, system, order" - and seek ways to exclude it. Campkin and Kristeva both draw attention to the violence that often undergirds this rejection of abject, through "spatialized processes... [in] which the subject, or society, attempts to impose or maintain a state of purity. ${ }^{24}$ Similarly, critical urban geographers argue that the neoliberal city has no room for the whole human body (with its production of excrement and potential for disease) in public space. ${ }^{25}$ The good citizen is one who knows to separate the private functioning of their body from public space. The street and the city's public spaces are to be clean, gentrified, free of pollution by Otherness. ${ }^{26}$ Any lingering trace of the organic body must be sanitized, erased and washed away. $^{27}$

Nevertheless, Douglas does not see pollution taboos as inherently oppressive:

In chasing dirt, in papering, decorating, tidying, we are not governed by anxiety to escape disease, but are positively re-ordering our environment, making it conform to an idea. There is nothing fearful or unreasoning in our dirt-avoidance: it is a creative movement, an attempt to relate form to function, to make unity of experience. ${ }^{28}$

Douglas catalogues the many creative ways cultures have adopted rituals to ease the integration of anomalous things and people. For example, in the Abrahamic traditions, the ritual of washing moves a person, object or space from the discursive code of "unclean" to "clean", "unbeliever" to "baptized", "profane" to "consecrated", "defiled" to "holy." ${ }^{29}$ Douglas argues that taboos are only "as repressive as the leading members of the society want them to be." If those who are in control "want a different way of life, the taboos will lose credibility and their selected view of the universe will be revised." 30

As a result, "pollution beliefs can be used in dialogue of claims and counter-claims to status." ${ }^{31}$ While the public character of our cultural classifications make them difficult to change, the existence of dirt opens the possibility for political change. Douglas argues that the reactionary impulse is not inevitable. We can derive aesthetic pleasure from surprise and difference. Anomaly "can be used in ritual...poetry and mythology...to enrich meaning or to call attention to other levels of existence." ${ }^{32}$ Consequently, it is possible to "deliberately confront the anomaly and create a new pattern of reality in which it has a place." ${ }^{33}$ Indeed, many cultures recognize dirt as a symbol of fertility - we use the word "dirty" to describe erotic behavior. One sees this potential in the dual meaning of the word germ: it can denote a pathogen or the seed that germinates into new life. In dirt lies the potential for a reordering of society. Embracing dirt, then, can be revolutionary.

\section{b. Neoliberalism and Its Discontents in Lower Manhattan}

Understanding the deployment of discourses of dirt and danger cannot be divorced from questions of context, in this case charting the relationship between neoliberalism and urban public space in New York. In doing so we must resist a totalizing narrative of neoliberalism: the wealth of work in geography and elsewhere has pointed to both the diversity of neoliberal practices and simultaneously warded against granting a fictive coherence to a plural and shape-shifting set of political and economic 
agendas. ${ }^{34}$ But this does not necessitate avoiding the term or ignoring some general spatial trends. If we can trace a broad political philosophy of neoliberalism it centers on a normative impulse that the market is better than the state at distributing public resources coupled with an emphasis on the selfresponsibility of the individual. Such abstractions have had profound urban spatial effects, experienced on an uneven but global scale; evidenced in the privatization of public space, the 'splintering' of public infrastructures and the gentrification of inner city neighborhoods. ${ }^{35}$ In these circumstances, new conditions are imposed upon the individuals within public space, often expressed through demands for certain forms of behavior and bodily comportment coupled with new restrictions on access linked to the ability or desire to consume. To return to Douglas's terminology, it is such neoliberal reworking of space that revise prevailing pollution taboos, producing new accounts of dirt and danger connected to the judgement of bodies an matter in space.

New York City has, for a number of decades, been a key terrain for struggles over the right to the city under neoliberal transformations. The most recent transformation in the city's urban landscape can be traced to industrial transformations in the 1970s. The deindustrialization of the city and subsequent economic realignment privileging the financial, entertainment and tourism sectors has reshaped the city's spatiality. As blue collar jobs in New York's manufacturing industry and ports disappeared, swaths of Downtown Manhattan's industrial zones - the Meatpacking District, SoHo (South of Houston Street), Greenwich Village and Lower East Side were left vacant or under-occupied. Former factories and nearby low-rent buildings were colonized by artists, homeless people and creative workers who used the large underoccupied 'lofts', tenements and 'brownstones' for housing, gallery and studio space. This represented a kind of enclosure of space, but it was often represented as a form of 'revitalization' of neighborhoods, a 'revival' of community in 'dying' areas of the city. The emergent 'scene' attracted a new wave of middle class urban professionals back into the urban core, resulting in a displacement, through the market, of poor and working class people unable to afford rising prices and rents. Rezoning and deregulation has allowed for commercial development of real estate, corporate encroachment and the further development of high-rise and luxury apartment buildings in these neighborhoods. Thus "gentrification" - often represented simply as an economic process - occurred not only through market mechanisms; it was the result of a complex of social and political systems. ${ }^{36}$

Gentrification of New York's post-industrial landscape occurred simultaneously with increasingly aggressive policing of the city's streets and public areas, in which Mayor Rudolph Guiliani and other local officials portrayed their efforts as "cleaning up" the city. Drawing on the 'Broken Windows' theory of policing, ${ }^{37}$ homeless people, the mentally ill, prostitutes, drug users, street hawkers and protestors were portrayed as vectors of social problems and their presence in the city streets and parks was effectively criminalized, or at least tightly circumscribed. ${ }^{38}$ Times Square, the city's primary entertainment district was 'cleared' of many of its strip clubs, adult movie theatres, street performers and informal merchants in favor of its current commercialized and firmly policed character, where even vertical space has been commodified through brash, overwhelming advertising. ${ }^{39}$ Minority communities have borne much of the brunt of this coercive assertion of state control over the streets, with police 'stop and frisk' policies leading to the arrest of many young people of color for minor offences. ${ }^{40}$ Removing 'the wrong kind of people' from public view, the twin processes of gentrification and aggressive policing have aimed to 
'sanitize' New York City, pathologizing those who do not fit into the neoliberal vision of the corporate city - "a pro-business city," as Giuliani called it. ${ }^{41}$ Giuliani openly stated that he wished to rid the poor from New York City's public spaces. ${ }^{42}$ As with Robert Moses' fixation with eliminating 'blight' from the urban landscape in the 1950s and 1960s, the discourse of 'cleaning up' the city frames the poor, the 'strange', the sex worker and the petty criminal as contaminants, vectors of disease and social contagion rather than citizens. Christopher Glazek has argued that "The eerie sense of security that prevails on the streets of lower Manhattan obscures, and depends upon, a system of state-sponsored suffering" - the large-scale incarceration of the city's underclass. ${ }^{43}$ Dissenters, in this context, are cast as disrupters of the new, calm urbanity: "Protest... have come to be viewed by many urban elites not as signs of a healthy democracy or a vibrant civil society but as another symptom...of urban disorder." ${ }^{44}$

However, like others we are keen to understand neoliberal enclosure in New York as one side of a dialectic, where the withdrawal of public goods and shrinking of the public sphere is met with increasing challenge and subversion. ${ }^{45}$ Hence the encroaching neoliberal enclosure of Lower Manhattan has not happened without resistance, ranging from petty criminal behavior to art, graffiti, hip hop and poetry and larger disruptions of the established order. ${ }^{46}$ One particularly notable example was the 1988 'uprising' or 'riot' (depending on the accounts) over Tompkins Square in the East Village, where local residents, activists and homeless people living in the park clashed with police in protest against gentrification and rising rents. ${ }^{47}$ In 1996 the 'Battle for Tompkins Square' was immortalized in the musical Rent, which, in retelling La Boheme, brought to the Broadway stage a searing indictment of the notion of New York City as a 'clean' corporate city. Through its representation of the human impact of AIDS, it problematized discourses of 'contamination' and 'protection. ${ }^{48}$

The appearance of Occupy Wall Street in 2011 drew upon and refashioned this history of resistance, though also faced the repressive reaction it has all-too-often engendered. OWS brought intersecting social movements together in the physical space of Zuccotti Park, a privately-owned public space (POPS) in Lower Manhattan's Financial District. OWS was a "palimpsest" of numerous overlapping demands and networks of activists working on an array of social justice and peace issues. ${ }^{49}$ However, they coalesced around a message of discontent with economic inequality and, in New York City, differential access to the city's economy, services, housing, public spaces and justice system. This was dramatized through the discursive device opposing the "99\%" against the "1\%" - with Occupied Zuccotti Park (redubbed "Liberty Square") and Wall Street as synechdotic opponents.

Crucially, OWS activists in Lower Manhattan often objected to being characterized as "protestors" preferring identification as "demonstrators" - because they saw their encampment, assemblies and marches as a demonstration of a) the undeniable human reality of the people exploited by the capitalist system b) the potential collective power of the $99 \%$ and c) an alternative, inclusive urbanism to the canyon of financialized skyscrapers surrounding them. A key element of OWS' emergent strategy consisted of placing "unwanted" human bodies into spaces where, through systems of exclusion and marginalization, they had previously been unwelcome. Bolton et al describe this as a social and symbolic "de-gentrification" of the Financial District - noisily contesting the city's discriminatory policies, procedures and practices, whether explicit or implied..$^{50}$ Occupy's alter-city developed systems for serving food, providing medical care, processing waste, providing power and internet connections and 
resolving internal disputes. This served as an affront to the city's dominant planning and architecture deliberately "misusing" the streets and parks in ways that mismatched their intended form as gentrified neoliberal spaces. OWS was, in effect, a kind of colorful "human graffiti", transgressing the codes implicit and explicit - that governed Lower Manhattan. As Brash observes, "By locating itself in a visible public space on a $24 / 7$ basis, Occupy Wall Street violated the ordering principle of protest in the neoliberal city: that dissent should be permitted but not seen or heard." ${ }^{51}$

Unsurprisingly, the Occupation was not welcomed by all of the city's residents and leaders. It was seen by the Mayor Bloomberg administration, the financial sector and the tabloid press as a disorderly intrusion. As we will explore in more depth below, the Occupation's opponents sought not so much to engage Occupiers' arguments but to cast them as disruptive, unproductive, dirty, a contagious health risk and an aesthetic affront to the serenity of Downtown. As noted by Julian Brash, "charges of uncleanliness were a signal that the occupation had violated notions concerning the ordering of urban space, and in particular the proper place of urban political dissent. ${ }^{\prime 52}$

\section{c. OWS as Unproductive and Dirty}

Theda Skocpol and Vanessa Williamson argue that the Tea Party and populist right in the US have discursively divided the country between those Americans they see as "hard working" and thus deserving reward and those they see as "free loading": youth, minorities, immigrants, artists and intellectuals. 'Free loaders' are often then depicted as vectors of both literal disease and metaphorical social maladies. ${ }^{53}$

Skocpol and Williamson show that one's depiction as "hardworking" has little to do with one's actual employment status, rather it is a discursive coding. It relates to a specific kind of instrumental and quantifiable work (that contributes to the production-consumption-growth cycle) as well normative notions of gender and social roles, including the male breadwinner and house wife. For example, at an OWS demonstration in Times Square, one of the authors (Matthew Bolton) tried to counteract some of this reaction by holding a sign saying, "I have a PhD from the London School of Economics, a good job and a nice suit. I stand with the 99\%." He was surprised when several passers-by continued to shout at him "get a job!" or "you should have majored in something useful!" Being a member of Occupy immediately discursively coded him as a "freeloader"; no matter his employment status or educational achievement, he was not a member of the "hardworking." Likewise, despite the common OWS claim that it was a movement of people who wanted jobs, their "freeloading" off the commons marked them as targets for contempt and censure. Within the neoliberal discourse of people like Gingrich, citizenship depends upon being among the "hardworking." Gingrich was literally telling Occupiers to "know their place', to locate themselves within economic workspace (and traditional cultural/social structures) not protest-space.

While he expressed his views with less contempt than Gingrich, Mayor Bloomberg similarly chided Occupiers. By protesting financial institutions, he said, Occupiers were blaming on the "wrong people" for their economic troubles. Bloomberg portrayed bankers as entrepreneurs and job-creators: "If the banks don't go out and make loans, we will not come out of our economic problems, we will not have 
jobs." Instead of demonstrating, he said New York citizens and government should do "anything we can do to responsibly help the banks" create jobs and "support their employers." ${ }^{54}$ By October, his tone had become sterner. He called the Occupation "not productive" and accused the Occupiers of "trying to...take the jobs away from people working in this city." By threatening the financial services - "a big part of our economy" - Bloomberg said the Occupiers would reduce the municipal tax base: "we're not going to have any money to pay our municipal employees or clean our parks or anything else." ${ }^{55}$ For Bloomberg then, citizenship is about assisting capital to be "productive" ("hardworking"); being "not productive" (a "freeloader"), or protesting those that are, threatens the very viability of city. In this, Bloomberg is drawing on a neoliberal notion of the "market citizen" who "recognizes the limits and liabilities of state provision and embraces her obligation to become more self-reliant." ${ }^{56}$ Of course, this attitude ignored the productivity of Occupy, even in a classic sense. Occupiers made meals for each other, produced art, media and entertainment, wrote new software, cared for people with humanitarian needs and made their own shelters. Indeed, one could argue that in OWS's "prefigurative politics" they felt an acute need to build and produce the material, discursive and affective evidence of their vision. ${ }^{57}$ However, this labor remained invisible in the neoliberal frame and instead Occupiers were framed as wasteful - even dirt themselves.

In demanding Occupiers "take a bath", Gingrich evoked discourses that define worthiness - godliness in terms of cleanliness and purity. FOX News reported that Gingrich's riposte "obliterates OWS." "58 "To obliterate" literally means to wipe out, erase or delete text; Gingrich and FOX thus aimed to erase OWS from the space of Lower Manhattan. Occupy's alternative text and narrative for Zuccotti Park was framed as a sullying of the space, which needed to be cleaned. By contrast, articles in the right-wing press fixated on the dirtiness of OWS, which was seen as discrediting its agenda - a sort of 'politics of hygiene' - such as the following excerpt from the conservative tabloid, New York Post

Close this pigpen! Filth-ridden Zuccotti Park is a breeding ground for bacterial infection loaded with potential health-code violations that pose a major risk to the public, an expert who inspected the area warned. "It's like Walmart for rats," Wayne Yon, an expert on city health regulations, said yesterday. ${ }^{59}$

This focus on OWS as a threat to the purity of Lower Manhattan was expressed more subtly by Mayor Michael Bloomberg and Brookfield Properties, the owner of the site, whose initial reaction was relatively subdued. Brookfield's primary objection to OWS was that they were preventing the proper cleaning of the park, playing into discourses of contamination: "Sanitation is a growing concern. ... Because many of the protestors refuse to cooperate by adhering to the rules, the park has not been cleaned ... and as a result, sanitary conditions have reached unacceptable levels." ${ }^{160}$ After visiting the park in October, John Zuccotti, Brookfield's chairman, described it as "a little messy," saying that "Sooner or later we're going to have to get in to clean it." ${ }^{61}$ Similarly, Mayor Bloomberg said he was "worried about sanitation" ${ }^{62}$ and "reports in the papers of people defecating in alleys and that sort of thing...."

This discourse seeped into mainstream media descriptions of OWS. New York's CBS affiliate called Zuccotti Park a "Petri dish of germs": 
It's not only the noise from the drums or the free spirited topless dancers who perform for swarms of speechless gawkers that are creating a quality of life crisis at Zuccotti Park. Now there is concern about a potential public health menace - disease. $^{64}$

This excerpt reveals much about how OWS was perceived as a threat to a sanitized, neoliberal, businessfriendly Downtown. Drumming and "free spirited topless dancers" are perceived as contributing to "quality of life" problems and subtly associated with the "menace" of "disease." The perceived eroticism of female Occupiers - who draw "gawkers" - is seen as a threat to a quiet, restrained bourgeois Lower Manhattan life. Note the use of the word "swarm" - usually used for insects - to describe those gathering in the park and the term "quality of life", which is associated with Guiliani-era 'Broken Windows' approach to policing public behavior. This quotation illustrates how the right-wing discourse reacting against OWS associated the perceived 'dirtiness' of Occupiers with their disruption of 'quality of life', the linking of bodily disease with social disease. ${ }^{65}$

As New York Times columnist Nicholas Kristof pointed out, "Many locations aren't so clean and safe, but there aren't hundreds of officers in riot gear showing up in the middle of the night to address the problem.." ${ }^{\prime 66}$ The Occupiers' perceived lack of hygiene itself was not what was so threatening. Rather their Otherness threated gentrified, tourist-friendly Lower Manhattan. Rather than collaborating with OWS to improve sanitation and public health in Zuccotti Park, the hygiene critique was offered antagonistically. Consistent with notions of neoliberal "market citizenship", OWS was expected to be self-reliant, to manage its own waste removal, sanitation and public health problems. Their failure to do so effectively was perceived as evidence of their lack of "hard work." The Occupation was associated with that quintessentially New York fear - a bed bug infestation. They were portrayed as parasitic creatures that fed off the work of others, bearing disease, difficult to eradicate, able to leap from one space to another, invading clean, relaxed, private space. Brash also turns to Mary Douglas to explain these anxieties:

OWS was politics out of place, a politicizing contagion that threatened the ostensibly inevitable centrality of finance, and of the profound inequality that has accompanied it, to the contemporary city. It was this transgression against the political ordering of the neoliberal city that generated the concern with filth, cleanliness and sanitation.... ${ }^{67}$

In mid-October 2011 city officials announced that Zuccotti Park would be closed "temporarily" for cleaning. ${ }^{68}$ But OWS was afraid that if they left the park, they would not be allowed back. The OWS Sanitation Working Group thus organized a massive cleaning of the park, urging Occupiers to pick up trash, sweep the park and bleach surfaces. They consciously used this as an opportunity to counteract the depiction of OWS as dirty, branding the event Operation \#wallstcleanup and making the broom a symbol of the movement. A banner in park provided the following "To Do List":

Clean up:

[ ] The Park

[ ] The Political Process

Meanwhile, OWS organizers called on all people associated with the movement to pack into Zuccotti Park at the time scheduled for cleaning; some 3000 people materialized early in the morning, many 
wielding brooms. Faced with the large crowd of protestors, Brookfield canceled the cleaning and New York's Deputy Mayor Caswell Holloway issued a statement saying that Brookfield "believes they can work out an arrangement with the protesters that will ensure the park remains clean, safe, available for public use...." ${ }^{69}$ The pressure to appear "clean" in the ensuing weeks saw Occupy adopt a panoply of systems and techniques to order, discipline and sanitize - perhaps even gentrify - the Occupation. Working groups on Sanitation, Town Planning, Architecture, Fire Safety and Security reorganized the Park into functional zones, with clear pathways and a waste disposal service. Rumors that the encampment was attracting a criminal element, a perceived growth in drug use and an alleged sexual assault in the park made many Occupiers feel unsafe. Minutes of an October 2011 Town Planning meeting expressed the widespread alarm in discourses of sanitation and infestation, "We are being attacked [by] a virus from the outside" and overwhelmed by "undesirables." They discussed the possibility of establishing an "identification system", such as "wristbands" to determine unwanted outsiders. Another person stated that the group should "create environments where people who shouldn't be here DON'T want to be here." ${ }^{70}$ In November 2011, a pro-Occupy website used Guiliani's phrase to describe how the Occupation was "Improving Quality of Life" in the park, through sanitation and better toilets, tightened security, reduced noise levels and improved relations with the surrounding business community. ${ }^{71}$ These attitudes prompted considerable dissention about whether Occupy was marginalizing poorer and more bohemian activists in favor of the more 'presentable' face of the Occupation. $^{72}$

Even the "arrangement" with Brookfield, however, was seen as insufficient. When the NYPD raided and cleared out the park on 15 November 2011, they were accompanied by workers and garbage trucks from the city's Department of Sanitation. Before moving in on the Occupiers, the police told them that they must leave because "This is a health hazard", a term echoed by Bloomberg in his justification of the raid. ${ }^{73}$ Brookfield issued a statement claiming Zuccotti Park had become "dangerous, unhealthy and unsafe." ${ }^{74}$ Zuccotti Park was then effectively re-enclosed, as the NYPD and Brookfield erected metal barriers around the park (ignoring a temporary court injunction telling them to take them down), while every residual trace of the occupation was powerwashed away. By re-ordering the space, both physical and symbolic, in Zuccotti Park, OWS was considered literally 'disorderly.' By placing the wrong bodies 'unproductive', 'strange' and 'Other' - into the wrong spaces at the wrong times, OWS people and structures were perceived by their opponents as a form of pollution. To re-impose order on Lower Manhattan the Occupation had to be purged and the space ritually washed to make it pure and, to use a phrase from The Atlantic, "once again open for business." ${ }^{\prime 75}$ But this authoritarian reaction also indicate the level of threat the City's elite felt in OWS. As Brash puts it, "Calling the occupiers 'filth' - though meant as an insult - was in fact a profound compliment, an acknowledgement of the transformative potential inherent in OWS." 76

\section{d. Demonstrating Productivity through Cleaning Up after Sandy}

Following its eviction from Zuccotti Park, OWS continued to engage in demonstrations around New York City. Organizers also turned their attention to initiatives like the Rolling Jubilee campaign, which sought creative ways to address the overwhelming debt burden on the poor. ${ }^{77}$ However, the focused energy of the Zuccotti Park Occupation - while returning in occasional ebbs and flows - slowly dissipated. ${ }^{78}$ 
Then, on 29 October 2012, Hurricane Sandy hit New York City. The Category 2 storm caused tremendous devastation, particularly affecting marginalized waterfront communities such as Red Hook and the Rockaways. Lower Manhattan, including Zuccotti Park, lost power for several days. Alarmed by the scale of destruction and the slow response from the City government and Federal Emergency Management Agency (FEMA), Occupy activists quickly reactivated "networks and skills" that they had established in the Zuccotti Park and "mobilised into an effective relief effort." "B9 "Being among the first to move made Occupy a vital part of the city's hurricane relief infrastructure," said Time magazine. According to Cornish et al, "Occupy Sandy volunteers distributed food and blankets, repaired communications networks and restored properties - and were widely recognized as doing so more effectively and swiftly than the official relief effort." ${ }^{80}$ At the height of Occupy Sandy's mobilization, it had "an estimated 60,000 volunteers - more than four times the number deployed by the American Red Cross." ${ }^{81}$

Some traditional relief organizations, such as the Red Cross, were nervous of being contaminated by Occupy's political agenda. ${ }^{82}$ However, in "organizing donations and volunteers" ${ }^{83}$ and making sophisticated use of technologies like Twitter, Facebook and the Amazon.com wishlists (to purchase supplies), Occupy Sandy was mobilizing capital, labor and technology to move goods and offer services. Cornish et al argue, "This emergent effort affirms the creative and generative value of community networks" like Occupy Sandy. ${ }^{84}$ The speed and reach of Occupy Sandy gained widespread respect and they soon found themselves working with unexpected partners, from the police to the National Guard. ${ }^{85}$ In its After-Action Report, FEMA reported that it "worked closely" with Occupy Sandy. ${ }^{86}$ In one unexpected moment, "FEMA and NYPD officers joined in chanting 'We are unstoppable, another world is possible' with Occupy Sandy volunteers helping at Far Rockaway." ${ }^{87}$ Occupiers felt particularly vindicated when, confronting Bloomberg as he visited the Rockaways, he told them, "Thank you for everything you've done. You guys are great. ... We really do appreciate it, all kidding aside. You really are making a difference. ${ }^{\prime 88}$ An evaluation of the relief effort conducted for the US Department of Homeland Security praised Occupy Sandy as "one of the leading humanitarian groups providing relief to survivors across New York City and New Jersey." ${ }^{\prime 89}$ The local and national authorities were recognizing - if begrudgingly - that Occupiers were being productive. As FEMA put it, Occupy Sandy's "Youthful Energy and Idealism Tackles Real-World Problems." ${ }^{\prime 90}$ As the relief effort wound down, Occupy Sandy turned its attention to the long-term "rebuilding" effort, again demonstrating that it wanted to be a productive part of the city's recovery. For example, they worked in partnership with a community resource center YANA Rockaway, whose mission "is to help job-seekers develop their employability" and "to bring employment opportunities to the community."

Occupy Sandy also framed their work in discourses of "clean-up." One call for volunteers described the work as "people helping people to pick up the pieces of a life, and with each person working, each couch thrown away, each wall pulled down, a little more healing, peace, friendship and light enters the world." ${ }^{\prime 2}$ In fact, Occupy Sandy deliberately focused its attention on communities like Red Hook and Rockaway that were on the peripheries of the city and had long been treated as "dumping grounds" for social problems by the city. ${ }^{93}$ In helping to "clean-up" poor and marginalized areas, Occupy Sandy was proclaiming solidarity with the supposedly unproductive edges of the city. ${ }^{94}$ In numerous press articles, 
Occupy Sandy organizers expressed the sense that they "need people who are willing to go out in the field and get their hands dirty": "We don't need deodorant, we need drywall."

But in using imagery of productivity and cleaning, their tone was different than when such discourses were deployed against the Zuccotti Park Occupation. For Occupy Sandy, productivity was rooted in notions of solidarity, mutual aid and collective action, rather than capitalistic competition. For example, Occupy Sandy allocated $\$ 60,000$ to support the development of worker-owned cooperatives. "It's about reorganizing the economy," explained the funder of the project, so that "workers [are] controlling capital, instead of capital controlling workers." ${ }^{16}$ One study also found that many Occupy Sandy volunteers "were unemployed or underemployed and were eager to share their skills", such as in construction, plumbing, wiring, logistical management and software coding, with people in the affected communities: "Occupy Sandy tried hard not to provide just charity. Instead it encouraged members to engage survivors at a very humane level." ${ }^{97}$

However, while Occupy Sandy was among the first to move in the aftermath of the storm and in many areas dominated the relief effort, they have been marginalized from the large-scale recovery work that came later. One Occupy Sandy worker described the relationship this way: "We were worried that the Red Cross and FEMA weren't doing so well, though they're definitely at a scale that we can't match and shouldn't try.... We're sort of like the water that's filling in the cracks." ${ }^{98}$ However, many Occupiers were uncomfortable with the role of "filling in the cracks" left by the state and worried that they were being tainted by cooption..$^{99}$ Occupy's original vision was a revolutionary one, not of administering social services abandoned by the revanchist state. As the emergency relief phase drew down, many Occupiers again began looking for a way to again challenge the status quo. ${ }^{100}$ Indeed, Occupy Sandy organizers were insistent that the humanitarian disaster faced by New York City was not a "natural" one - it was created by a political and economic system that had ignored the devastation of the climate, the degradation of public infrastructure, the gutting of social services and marginalization of the poor. Shortterm relief, while an important expression of solidarity, was not enough. ${ }^{101}$

\section{e. Flooding Wall Street: Concluding Reflections}

On 22 September 2014, a day after more than 300,000 people had marched through New York in favor of action on climate change, 2,000 people gathered in Battery Park at the southernmost tip of Manhattan. Many of the people in attendance were former Occupiers - email announcements had reactivated long-moribund Occupy-related listserves. Demonstrators had been told to wear blue and many carried wood-cut banners with the slogan "Stop Climate Chaos \#FloodWallStreet". The image on the banner depicted the Financial District cityscape with black pollution clouds rising from the skyscrapers and forming a storm-cloud raining down on a blue wave made up of people flowing into the city. This artwork represented Wall Street - as a metonym for the neoliberal capitalistic system - as the source of contamination and degradation. By contrast the "People" - the demonstrators themselves were the source of the cleansing, baptizing flood. As one protestor put it, "Two years ago, Superstorm Sandy literally flooded New York's Financial District - but it didn't faze Wall Street and their drive for the short term profits that flow from the cooking of the planet.... Which is why we're going to flood them again." ${ }^{102}$ Here, the protester symbolically occupies the devastating power of Sandy, but turns it 
not on the poor and marginalized communities it hit most hard, but on the perceived source of the deluge - the neoliberal economic system. ${ }^{103}$ At one point, organizers instructed everyone to be silent and thump their chest in a heartbeat rhythm to symbolize the flow of water through the body and to remember that "the oil that they [the capitalist system] are extracting is the blood of the earth." In effect, the Flooders were claiming their very organic and sanguine nature, re-inserting the feral and fecund body back into the concrete and asphalt of the neoliberal city.

This paper has sought to illustrate, theorize and contest the deployment of discourses of dirt and danger in twenty first century urban protest in New York City. The passage of the last decade has seen the multiple deployment of uncleanliness and threat. First, and stemming from the title of the paper, we have traced how such labels were used to discipline, denigrate and finally remove those who occupied public space in New York City in order to challenge the inequities of the global financial system. By violating neoliberal privatized zoning of the city, Occupiers were cast as unproductive, dirty and out of place. Sullied, Zuccotti Park needed to be recleansed, resanitized, regentrified and made safe for 'hardworking', clean Americans. The dehumanization implicit in this discourse is troublingly authoritarian, as is the implication that democratic protest "unproductive." Second, we have examined the nested scales (and temporalities) of discourses of dirt, as late in the action protestors at Zucocotti Park appropriated conflations of dirt and danger to marginalize people in their midst. Finally, activists drew on the discursive resources of dirt and danger to challenge political and economic elites. Rather than reusing accounts of dirt and danger, such actions seek to provoke a public debate as to who, what and where is understood as 'dirty', particularly in the light of global environmental crisis and the overextraction of finite resources. They occur not simply as 'reactions' against repression but rather as simultaneously cacophonous competing frames.

Indeed, as Douglas argued in Purity and Danger, discourses of cleanliness and productivity can be sites of contestation and creativity. The desire to arrange one's environment is not necessarily a negative one, particularly if society can wrestle with inevitable anomalies openly and honestly. In producing a new way of inhabiting a city park and in providing relief after disaster, Occupy offered alternative visions of productivity, rooted in mutual aid, solidarity and co-creation. Occupiers could get their hands 'dirty', germinating new possibilities in the fertile ferment of working together. In cleaning up the destroyed urban peripheries after Sandy and flooding Wall Street with protestors, Occupy inverted discourses of cleanliness, challenging conventional understandings of who was dirty, corrupting or polluting. In Occupy we have seen intimations of an alternative urbanism - a "countergeography"104 or "rebel city"105 - which opens space for Otherness, by bringing anomalous people into the core and engaging in solidarity with the rejected peripheries.

\section{ENDNOTES}

${ }^{1}$ Newt Gingrich. "Newt Obliterates OWS: 'Go Get A Job Right After You Take A Bath."' FOX Nation. (20 November 2011). <http://nation.foxnews.com/newt-gingrich/2011/11/20/newt-obliterates-ows-go-get-job-right-after-youtake-bath>. Accessed 18 May 2012.

2 Ezra Klein. "Romney's theory of the 'taker class,' and why it matters." The Washington Post. (17 September 2012) $<$ http://www.washingtonpost.com/blogs/wonkblog/wp/2012/09/17/romneys-theory-of-the-taker-class-and-whyit-matters/>. 
${ }^{3}$ Julian Brash. "Politics Out of Place: Occupy Wall Street and the Rhetoric of Filth." In: Beyond Zuccotti Park: Freedom of Assembly and the Occupation of Public Space. Ronald Shiffman, Rick Bell, Lance Jay Brown and Lynne Elizabeth (Eds.). (Oakland, CA: New Village Press, 2012). pp. 61-66.

${ }^{4}$ In: Jonathan Marvel. "Public Space: Opening Streets and Sidewalks." In: Beyond Zuccotti Park: Freedom of Assembly and the Occupation of Public Space. Ronald Shiffman, Rick Bell, Lance Jay Brown and Lynne Elizabeth (Eds.). (Oakland, CA: New Village Press, 2012). pp. 337-338.

${ }^{5}$ Don Mitchell. The right to the city: Social justice and the fight for public space. (New Yok: Guilford Press, 2003).

${ }^{6}$ Emily Welty, Matthew Bolton and Nick Zukowski. "Occupy Wall Street as a Palimpsest: Overview of a Dynamic Movement." In: Occupying Political Science: The Occupy Wall Street Movement from New York to the World. Emily Welty, Matthew Bolton, Meghana Nayak and Christopher Malone (Eds.). (New York, Palgrave Macmillan, 2013). pp. 25-57.

${ }^{7}$ Mary Douglas. Purity and Danger: An Analysis of Concepts of Pollution and Taboo. Routledge Classics Ed. (New York: Routledge, 2002). pp. 40-45.

${ }^{8}$ Douglas. Purity and Danger. p. 85.

${ }^{9}$ Douglas. Purity and Danger. p. xvii.

${ }^{10}$ Douglas. Purity and Danger. p. xi.

${ }^{11}$ Douglas. Purity and Danger. p. xii.

${ }^{12}$ Douglas. Purity and Danger. p. xiii.

${ }^{13}$ Douglas. Purity and Danger. p. 44.

${ }^{14}$ Zygmunt Bauman. Wasted Lives. (Cambridge, UK: Cambridge, University Press, 2004); see also Don Mitchell. (1997) "The Annihilation of Space by Law: The Roots and Implications of Anti-Homeless Laws in the United States." Antipode. 29(3). pp. 303-355.

${ }^{15}$ Mark Wigley. White Walls, Designer Dresses. (Cambridge, MA: MIT Press, 2001).

${ }^{16}$ Wendy Brown. Walled States, Waning Sovereignty. (Cambridge, MA: MIT Press, 2010)

${ }^{17}$ Douglas. Purity and Danger. p. 10.

${ }^{18}$ Douglas. Purity and Danger. p. 48.

${ }^{19}$ Douglas. Purity and Danger. p. 46.

${ }^{20}$ Stanley Cohen. States of Denial: Knowing about Atrocities and Suffering. (Cambridge, UK: Polity, 2001).

${ }^{21}$ Douglas. Purity and Danger. p. 46.

${ }^{22}$ Douglas. Purity and Danger. p. 92.

${ }^{23}$ Yandi Andri Yatmo. (October 2008) "Street Vendors as 'Out of Place' Urban Elements." Journal of Urban Design. 13(3). pp. 387-402.

${ }^{24}$ Ben Campkin. (2013) “Placing 'Matter out of Place': Purity and Danger as Evidence for Architecture and Urbanism." Architectural Theory Review. 18(1). p. 56; Julia Kristeva. Powers of Horror: An Essay on Abjection. (New York: Columbia University Press, 1982).

${ }^{25}$ e.g. David Harvey. Rebel Cities: From the Right to the City to the Urban Revolution. (London: Verso, 2012); Stephen Graham. Cities under Siege: The New Military Urbanism. (London: Verso, 2011); Mike Davis. Planet of Slums. (London: Verso, 2006).

${ }^{26}$ Alan Hyde. Bodies of Law. (Princeton, NJ: Princeton University Press, 1997). pp. 259.

${ }^{27}$ Mitchell. "The Annihilation of Space." pp. 303-355.

${ }^{28}$ Douglas. Purity and Danger. p. 3.

${ }^{29}$ Douglas. Purity and Danger. pp. 40-45.

${ }^{30}$ Douglas. Purity and Danger. p. xiii.

${ }^{31}$ Douglas. Purity and Danger. p. 4.

32 Douglas. Purity and Danger. pp. 47-49.

${ }^{33}$ Douglas. Purity and Danger. p. 48.

${ }^{34}$ See Aihwa Ong Neoliberalism as Exception: Mutations in Citizenship and Sovereignty. (Durham, N.C: Duke University Press, 2006); J.K. Gibson-Graham. "The" End of Capitalism (as We Knew It): A Feminist Critique of Political Economy. (Minneapolis: University of Minnesota Press, 1996)

${ }^{35}$ Stephen Graham and Simon Marvin. Splintering Urbanism: Networked Infrastructures, Technological Mobilities and the Urban Condition. (Abingdon: Routledge, 2001) 
${ }^{36}$ Rosalyn Deutsche \& Cara Gendel Ryan. "The Fine Art of Gentrification." The MIT Press. 31. (Winter 1984); Neil Smith. The New Urban Frontier: Gentrification and the Revanchist City. (New York: Routledge, 1996); Lance Freeman. There Goes the Hood: Views of Gentrification from the Ground Up. (Philadelphia: Temple University Press, 2006); Jerilou Hammett \& Kingsley Hammett (Eds.). Suburbanization of New York. (New York: Princeton Architectural Press, 2007); Judith N. DeSena. The Gentrification and Inequality in Brooklyn: New Kids on the Block. (Lanham: Lexington Books, 2009); Miranda J. Martinez. Power at the Roots: Gentrification, Community Gardens, and the Puerto Ricans of the Lower East Side. (Lanham: Lexington Books, 2010); Suleiman Osman. The Invention of Brownstone Brooklyn: Gentrification and the Search for Authenticity in Postwar New York. (New York: Oxford University Press, 2011); Sharon Zukin. Naked City: The Death and Life of Authentic Urban Places. (New York: Oxford University Press, 2011).

${ }^{37}$ George L. Kelling \& James Q. Wilson. "Broken Windows." The Atlantic. (March 1982). <http://www.theatlantic.com/magazine/archive/1982/03/broken-windows/4465/>. Accessed 25 May 2012.

38 Judith A. Green. "Zero Tolerance: A Case Study of Police Policies and Practices in New York City." Crime and Delinquency. Vol. 45, No. 2. (April 1999). pp. 171-187; Phil Hubbard. "Revenge and Injustice in the Neoliberal City: Uncovering Masculinist Agendas." Antipode. Vol. 36, No. 4. (September 2004). pp. 665-686; Neil Smith. "Guiliani time: The revanchist 1990s." Social Text. No. 57. (Winter 1998). pp. 1-20; Neil Smith. "New globalism, new urbanism: Gentrification as global urban strategy." Antipode. 34. (2002). pp. 434-457

${ }^{39}$ Daniel Makagon. Where the Ball Drops: Days and Nights in Times Square. (Minneapolis: University of Minnesota Press, 2004); Lynne B. Sagalyn. Times Square Roulette: Remaking the City Icon. (Cambridge: The MIT Press, 2003); Lynn Cornelia. "Re-Inventing Times Square: Cultural Value and Images of 'Citizen Disney.'” In Critical Cultural Policy Studies: A Reader. Justin Lewis \&Toby Miller (Eds.). (Oxford: Blackwell, 2008); Samuel R. Delany. Times Square Red, Times Square Blue. (New York: NYU Press, 1999). William R. Taylor (Ed.). Inventing Times Square: Commerce and Culture at the Crossroads of the World. (New York: Russell Sage, 1992).

${ }^{40}$ Martin F. Manalansan IV. "Race, Violence, and Neoliberal Spatial Politics in the Global City." Social Text. Vol. 23, Nos. 3-4. (Fall-Winter 2005). pp. 84-85; "The Truth Behind Stop-and-Frisk." The New York Times.

<http://www.nytimes.com/2011/09/03/opinion/the-truth-behind-stop-and-frisk.html>. Accessed 16 May 2012.

${ }^{41}$ Rudolph Giuliani. Speech at Harvard's Kennedy School of Government. (29 September 1997).

<http://www.issues2000.org/2012/Rudy_Giuliani_Welfare_+_Poverty.htm>. Accessed 25 May 2012.

${ }^{42}$ Frank Lombardi, John Marzulli \& Kenneth R. Bazinet. "Rudy Plowing Ahead With Plan To Roust Homeless." New York Daily News. (23 November 1999). <http://articles.nydailynews.com/1999-11-

23/news/18110550_1_homeless-people-mayor-giuliani-grand-central-terminal>. Accessed 25 May 2012; David Firestone. "Without Welfare, Giuliani Suggests, Many Might Move." The New York Times. (29 April 1995).

<http://www.nytimes.com/1995/04/29/nyregion/without-welfare-giuliani-suggests-many-might-move.html>. Accessed 25 May 2012.

${ }^{43}$ Christopher Glazek. "Raise the Crime Rate." n+1. No. 13. (26 January 2012). <http://nplusonemag.com/raise-thecrime-rate>. Accessed 11 May 2012.

${ }^{44}$ Brash. "Politics Out of Place." p. 64.

${ }^{45}$ Alex Jeffrey, Colin McFarlane and Alexander Vasudevan. "Rethinking enclosure: Space, subjectivity and the commons." Antipode, 44(4), 1247-1267.

${ }^{46}$ Janet Abu-Lughod. From Urban Village to East Village: The Battle for New York's Lower East Side. (Cambridge: Wiley-Blackwell, 1995); Christopher Mele. Selling the Lower East Side: Culture, Real Estate, and Resistance in New York City. (Minneapolis: University of Minnesota Press, 2000).

${ }^{47}$ Andrew Jacobs. "A New Spell for Alphabet City; Gentrification Led to the Unrest at Tompkins Square 10 Years Ago. Did the Protesters Win That Battle but Lose the War?" The New York Times. (9 August 1998).

<http://www.nytimes.com/1998/08/09/nyregion/new-spell-for-alphabet-city-gentrification-led-unrest-tompkinssquare-10-years.html?pagewanted=all\&src=pm>. Accessed 11 May 2012.

${ }^{48}$ Naomi Tonooka. "Art and Urban Space: Rent, the East Village, and the Construction of Meaning." The Japanese Journal of American Studies, No. 19. (2008).

${ }^{49}$ Welty et al, “Occupy Wall Street as a Palimpsest: Overview of a Dynamic Movement", pp. 25-57. 
${ }^{50}$ Matthew Bolton, Stephen Froese and Alex Jeffrey. “This Space Is Occupied! The Politics of Occupy Wall Street's Expeditionary Architecture and De-gentrifying Urbanism." In: Occupying Political Science. (see note 46). pp. 135161.

${ }^{51}$ Brash. "Politics Out of Place." p. 65.

${ }^{52}$ Brash. "Politics Out of Place." p. 64. Emphasis removed.

${ }^{53}$ Theda Skocpol and Vanessa Williamson. The Tea Party and the Remaking of Republican Conservatism. (Oxford: Oxford University Press, 2011).

${ }^{54}$ Michael Bloomberg in: Harry Siegel. “Mayor Bloomberg: 'We'll See' If The City Will Let Occupy Wall Street Continue." The Village Voice. (30 September 2011).

<http://blogs.villagevoice.com/runninscared/2011/09/mayor_bloomberg_28.php>. Accessed 19 May 2012.

${ }^{55}$ Michael Bloomberg in: "Michael Bloomberg: Occupy Wall Street is trying to destroy jobs." The Guardian. (8 October 2011). <http://www.guardian.co.uk/world/2011/oct/08/bloomberg-occupy-wall-street-jobs>. Accessed 19 May 2012.

${ }^{56}$ Janine Brodie. "Restructuring and the New Citizenship." In Rethinking Restructuring: Gender and Change in Canada. I. Bakker, (Ed.). (Toronto: University of Toronto Press, 1996). p. 131. See also: Barry Hindess. "Neo-liberal Citizenship." Citizenship Studies. Vol. 6, No. 2. (2002). pp. 127-143; Jan Jenson and Susan D. Phillips. "Regime Shift: New Citizenship Practices in Canada." International Journal of Canadian Studies. Vol. 14. (Fall 1996). pp. 11-36.

${ }^{57}$ John L. Hammond. "The Anarchism of Occupy Wall Street." Science \& Society. 79(2). pp. 288-313.

${ }^{58}$ Gingrich. "Newt Obliterates OWS."

${ }^{59}$ Antonio Antenucci \& Carl Campanile. "Health expert condemns park rats.' The New York Post. <http://www.nypost.com/p/news/local/manhattan/health_expert_condemns_park_rats_Vk7kl3EMepB4d2DkeFN mFL\#ixzz1vLzNXoaT>. Accessed 19 May 2012.

${ }^{60}$ Melissa Coley in: Adam Martin. (6 October 2011). "More on Who Controls Zuccotti Park." The Atlantic. <http://www.theatlanticwire.com/national/2011/10/more-who-controls-zuccotti-park/43414/>. Accessed 19 May 2012.

${ }^{61}$ Sam Roberts. "A Public Servant Whose Name Is Now on Protesters' Lips." The New York Times. (5 October 2011). <http://cityroom.blogs.nytimes.com/2011/10/05/zuccotti-by-roberts/>. Accessed 19 May 2012.

${ }^{62}$ Michael Bloomberg in: Jill Colvin. "Bloomberg Says Wall Street Protesters 'Blame the Wrong People.'” DNAInfo. (30 September 2011). <http://www.dnainfo.com/new-york/20110930/downtown/bloomberg-says-wall-streetprotesters-blame-wrong-people\#ixzz1vKLqOGI1>. Accessed 19 May 2012.

${ }^{63}$ Michael Bloomberg in: Ann Mercogliano. "Will 'Occupy Wall Street' Last The Winter? Protesters Preparing As If They Will." CBS New York. (8 November 2011). <http://newyork.cbslocal.com/2011/11/08/will-occupy-wall-streetlast-the-winter-protesters-preparing-as-if-they-will/>. Accessed 25 May 2012.

${ }^{64}$ Marcia Kramer. "Serious Health Concerns, Including Norovirus, Growing At Zuccotti Park." CBS New York. <http://newyork.cbslocal.com/2011/11/11/report-health-concerns-grow-at-zuccotti-park>. Accessed 25 May 2012.

${ }^{65}$ For further analysis on this discourse, see: Brash. "Politics Out of Place." pp. 61-66.

${ }^{66}$ Nicholas D. Kristof. "Occupy The Agenda." The New York Times. (19 November 2011). <http://www.nytimes.com/2011/11/20/opinion/sunday/kristof-occupy-the-agenda.html>. Accessed 18 May 2012. ${ }^{67}$ Brash. "Politics Out of Place." p. 65. Emphasis in original.

68 "Occupy Wall Street Protesters Believe Zuccotti Park Cleaning A Ploy To End Occupation." The Huffington Post. (13 October 2011) <http://www.huffingtonpost.com/2011/10/13/bloomberg-tells-occupywal_n_1008767.html>. Accessed 25 May 2012.

${ }^{69}$ Esmé E. Deprez, Joel Stonington and Chris Dolmetsch. "Occupy Wall Street Park Cleaning Postponed." Bloomberg. (14 October 2011). <http://www.bloomberg.com/news/2011-10-14/occupy-wall-street-park-cleaningis-postponed-as-14-protesters-in-custody.html>. Accessed 25 May 2012.

${ }^{70}$ New York City General Assembly Town Planning. (25 October 2011) “Town Planning Meeting Minutes." <http://www.nycga.net/groups/town-planning/docs/town-planning-meeting-minutes-10-25-2011>. Accessed 27 August 2015.

${ }^{71}$ OccupyWallSt. (4 November 2011) "Occupy Wall Street: Improving Quality of Life for the 99\%." <http://occupywallst.org/article/occupy-wall-street-improving-quality-life-99/>. Accessed 27 August 2015. 
72 Bolton et al. "This Space Is Occupied!" pp. 135-161.

73 In: Joe Kemp. (15 November 2011). "Rough Timeline of Zuccotti Park Raid." New York Daily News. <http://live.nydailynews.com/Event/Showdown_at_Zuccotti_Park_The_NYPDs_raid_on_Occupy_Wall_Street_NYC ?Page=0 >. Accessed 25 May 2012.

74 Brookfield Office Properties. "Statement From Brookfield on Zuccotti Park Eviction." Wall Street Journal. (15 November 2011. <http://blogs.wsj.com/metropolis/2011/11/15/statement-from-brookfield-on-zuccotti-parkeviction/?mod=google_news_blog>. Accessed 28 May 2012.

75 Eric Randall. "Zuccotti Park Is Once Again Open For Business." (3 January 2012) The Atlantic Wire. <http://www.theatlanticwire.com/national/2012/01/zuccotti-park-once-again-open-business/46925/>. Accessed 25 May 2012.

${ }^{76}$ Brash. "Politics Out of Place." p. 66.

77 Sam Frizell. “Occupy Wall Street Just Made \$4 Million of Student Loan Debt Disappear.” Time. (17 September 2014) <http://time.com/3393918/occupy-wall-street-student-loan-debt/>.

78 Todd Gitlin. "Where are the Occupy protesters now?" The Guardian. (17 June 2014) <http://www.theguardian.com/cities/2014/jun/17/where-occupy-protesters-now-social-media>.

${ }^{79}$ Flora Cornish, Cristian Montenegro, Kirsten van Reisen, Flavia Zaka and James Sevitt. (2013) "Trust the process: Community health psychology after Occupy." Journal of Health Psychology. 19(1). p. 64.

${ }^{80}$ Cornish et al. "Trust the Process." p. 64.

${ }^{81}$ Homeland Security Studies \& Analysis Institute. (30 September 2013) "The Resilient Social Network: @OccupySandy \#Superstorm Sandy." <https://s3.amazonaws.com/s3.documentcloud.org/documents/1357203/the-resilient-socialnetwork.pdf?_ga=1.66566126.1912051508.1424575168>. p. 1.

82 Justin Elliott and Jesse Eisinger. (11 December 2014) “How Fear Of Occupy Wall Street Undermined the Red Cross' Sandy Relief Effort." ProPublica. <http://www.propublica.org/article/how-fear-of-occupy-wall-streetundermined-the-red-cross-sandy-relief-effort>.

${ }^{83}$ Matt Richter. (2012) "Occupy Sandy." Disaster Medicine and Public Health Preparedness. 6(4). p. 324.

${ }^{84}$ Cornish, et al. "Trust the process." p. 64.

85 Jared Malsin. "Best of Enemies: Why Occupy Activists Are Working with New York City's Government." Time. (13 November 2012) <http://nation.time.com/2012/11/13/best-of-enemies-why-occupy-activists-are-working-withnew-york-citys-government/>.

${ }^{86}$ FEMA. Hurricane Sandy FEMA After-Action Report. (1 July 2013). <http://www.fema.gov/media-librarydata/20130726-1923-25045-7442/sandy_fema_aar.pdf>.p. 29.

${ }^{87}$ Allison Kilkenny. (5 November 2012) "Occupy Sandy Efforts Highlight Need for Solidarity, Not Charity." The Nation. <http://www.thenation.com/blog/171020/occupy-sandy-efforts-highlight-need-solidarity-not-charity>.

${ }^{88}$ In: Ben Yakas. (1 December 2012) "Video: Bloomberg Praises Occupy Sandy, 'You Guys Are Great.'” Gothamist. <http://gothamist.com/2012/12/01/video_bloomberg_praises_occupy_sand.php>.

${ }^{89}$ Homeland Security Studies \& Analysis Institute. "The Resilient Social Network." p. 1.

${ }^{90}$ FEMA. "Youthful Energy and Idealism Tackles Real-World Problems." (n.d.) <https://www.llis.dhs.gov/sites/default/files/Occupy\%20Sandy.pdf>.

${ }^{91}$ Occupy Sandy. (n.d.) "YANA: Spokescouncil Member." <http://occupysandy.net/?projects=the-restore-yanaproject>.

92 Occupy Sandy. (12 December 2012) "Clean-Up Volunteers in the Rockaways." <http://occupysandy.net/2012/12/respond-rebuild-clean-up-voluteers-in-the-rockaways/>.

${ }^{93}$ Lawrence Kaplan and Carol P. Kaplan. Between Ocean and City: The Transformation of Rockaway, New York. (New York: Columbia University Press, 2003).

${ }^{94}$ Alan Feuer. (9 November 2012) "Occupy Sandy: A Movement Moves to Relief." The New York Times. <http://www.nytimes.com/2012/11/11/nyregion/where-fema-fell-short-occupy-sandy-wasthere.html?pagewanted=all\&_r=0>.

95 Jason Nark. (4 December 2012) “Occupy Philly turns eyes on Sandy relief." Philly.com <http://articles.philly.com/2012-12-04/news/35572495_1_volunteers-guy-fawkes-predator-drones>. 
${ }^{96}$ In: Peter Rugh. (27 March 2013) “Occupy Sandy builds worker power in Far Rockaway.” Waging Nonviolence. $<$ http://wagingnonviolence.org/feature/occupy-sandy-builds-worker-power-in-far-rockaway/>.

${ }^{97}$ Homeland Security Studies \& Analysis Institute. "The Resilient Social Network." pp. 32, 51.

${ }^{98}$ Malsin. "Best of Enemies."

${ }_{99}$ Justin Elliott and Jesse Eisinger. (11 December 2014) “How Fear Of Occupy Wall Street Undermined the Red Cross' Sandy Relief Effort." ProPublica. <http://www.propublica.org/article/how-fear-of-occupy-wall-streetundermined-the-red-cross-sandy-relief-effort>.

${ }^{100}$ Evan Hill. (27 October 2013) "One year after Sandy, the flood of Occupy volunteers recedes." Al Jazeera America. <http://america.aljazeera.com/articles/2013/10/27/one-year-aftersandythefloodofoccupyvolunteersrecedes.html>.

${ }^{101}$ Emily E. Welty. (2014) “Occupy Wall Street as “American Spring'?” Peace Review. 26(1). pp. 38-45.

102 CBS News. "Protestors flood Wall Street over global climate change." CBS News. (22 September 2014) $<$ http://www.cbsnews.com/news/wall-street-sit-in-planned-on-climate-crisis/>.

${ }^{103}$ Skye Bougsty-Marshall. "A climate of disobedience: the coming destituent flood." ROAR Magazine. (22 September 2014) < http://roarmag.org/2014/09/flood-wall-street-destituent-power/>. ${ }^{104}$ Graham. Cities under Siege. pp. 348-385.

${ }^{105}$ Harvey. Rebel Cities. 